\title{
EFFECT OF ACTH ON WATER DISTRIBUTION IN MAN AS MEASURED BY ANTIPYRINE, T 1824 AND BROMIDE ${ }^{1}$
}

\author{
BY MORRIS ZIFF, JEROME SIMSON, AND JOSEPH J. BUNIM 2 \\ (From the Department of Medicine and The Study Group on Rheumatic Diseases, New York \\ University College of Medicine, New York, N. Y.)
}

(Submitted for publication March 17, 1952; accepted July 3, 1952)

The retention of salt and water by patients receiving ACTH and cortisone is well known (1). If sufficiently marked, rapid weight gain, edema and pulmonary congestion may result. It was considered of interest, therefore, to study the changes in plasma volume, extracellular fluid volume, total body water, and total body chloride occurring in patients receiving adrenocorticotropic hormone. A transient increase in the inulin space in patients treated with ACTH and cortisone and maintained on rigid salt restriction has been reported recently by Levitt and Bader (2).

\section{METHODS}

Five patients were studied; three had rheumatoid arthritis, one rheumatoid spondylitis, and one rheumatic fever with polyarthritis. Three patients were males and two females; their ages ranged between 28 and 53. In order not to limit the magnitude of the expected physiological changes, salt intake was not restricted. The amount of salt taken by shaker along with the regular hospital diet was, however, weighed daily, and proved to be relatively constant for each patient, varying between 1 and 3 grams per day.

Following a preliminary control study, the patients were treated with ACTH in dosages of 100 to $120 \mathrm{mg}$. per day $^{3}$ for about four weeks. Three patients, E. S., M. U., and G. R., received a supplement of 3 grams of $\mathrm{KCl}$ per day. Volume studies, determination of serum $\mathrm{Na}^{+}, \mathrm{Cl}^{-}$and $\mathrm{HCO}_{3}{ }^{-}$levels, complete blood and eosinophil counts, and determination of E.S.R. and hematocrit were done at approximately weekly intervals during treatment and also at intervals varying from six to 14 days following the end of ACTH administration.

1 Supported by grants from the Masonic Foundation for Medical Research and Human Welfare, and by research grant No. HG 909 A\&R, from the National Heart Institute of the National Institutes of Health, Public Health Service.

2 Now at the National Institute of Arthritis and Metabolic Diseases, National Institutes of Health, Bethesda, Md.

3 This was pork ACTH, kindly supplied by Armour and Co. Dosage is expressed as milligrams equivalent to Armour Standard LA-1-A.
T 1824 space, antipyrine space and bromide space were measured simultaneously; total body chloride was estimated.

T 1824 space: Plasma volume was measured by the T 1824 dye method (3). Blood samples were taken 10 and 20 minutes following dye administration.

Antipyrine space: This was determined by the method of Soberman and his associates (4a). Approximately 1.5 grams of antipyrine were infused simultaneously with sodium bromide from a calibrated burette. The exact amounts of antipyrine as well as of bromide infused were established by direct analysis of the infused solutions. In non-edematous patients, samples were taken at two, three, four and five hours. In the two patients who developed significant peripheral edema, samples were taken at three, five, seven, and eight hours. It was demonstrated that the presence of $\mathrm{T} 1824$ dye in the plasma did not increase the ultraviolet absorption of the plasma filtrates at $350 \mathrm{~m} \mu$ after nitrosation, and it was concluded from this that $\mathrm{T} 1824$ does not interfere with the determination of antipyrine.

Bromide space: This was measured by the method of Brodie and Friedman (5). From 1.5 to 2 grams of bromide were infused as sodium bromide in $2 \%$ solution with the antipyrine. Correction for Donnan equilibrium and plasma water concentration was made by dividing the serum concentration by the factor 0.88 . Fusion of the plasma samples eliminated possible interference from $\mathrm{T} 1824$ and antipyrine in the analysis of bromide. When known amounts of bromide were added to plasma, 98 to $102 \%$ were recovered.

Brodie, Brand, and Leshin (6) have shown that bromide arrives at diffusion equilibrium in humans within 2.5 hours and Berger and his coworkers (7) have demonstrated that bromide equilibrates between plasma and pleural fluid in dogs in two to four hours. The latter authors and Dunning, Steele, and Berger (8) analyzed five hour blood samples in non-edematous patients. Eliel, Pearson, and Rawson (9) averaged the four and five hour samples. Bromide excretion has been neglected during the five hour period in the investigations cited because it comprises approximately $1 \%$ of the administered bromide (9). In order to establish the time of diffusion equilibrium of bromide, measurements of the bromide space were made in eight subjects not previously included; five were given no hormone, two received $\mathrm{ACTH}$

4 This substance was kindly provided in sterile ampules. by Eli Lilly and Co. 
TABLE I

Bromide space at varying intervals after infusion in untreated and ACTH treated patients to whom bromide had not been previously administered

\begin{tabular}{|c|c|c|c|c|c|c|c|c|c|c|c|}
\hline \multirow{2}{*}{ Patient } & \multirow{2}{*}{ Age } & \multirow{2}{*}{ Sex } & \multirow{2}{*}{ Wt. } & \multirow{2}{*}{ Disease } & \multirow{2}{*}{ Treatment } & \multirow{2}{*}{\begin{tabular}{|l} 
Daily \\
dosage
\end{tabular}} & \multirow{2}{*}{ Days } & \multicolumn{4}{|c|}{ Bromide space (liters) } \\
\hline & & & & & & & & $4 \mathrm{hr}$. & $5 \mathrm{hr}$. & $7 \mathrm{hr}$. & $24 \mathrm{hr}$ \\
\hline $\begin{array}{l}\text { K. S. } \\
\text { W. C. } \\
\text { T. T. } \\
\text { C. E. } \\
\text { A. S. } \\
\text { J. D. } \\
\text { T. T.* } \\
\text { P. G. }\end{array}$ & $\begin{array}{c}y r s . \\
29 \\
42 \\
14 \\
22 \\
58 \\
62 \\
14 \\
52\end{array}$ & $\begin{array}{l}\mathbf{F} \\
\mathbf{F} \\
\mathbf{M} \\
\mathbf{M} \\
\mathbf{M} \\
\mathbf{M} \\
\mathbf{M} \\
\mathbf{M}\end{array}$ & $\begin{array}{c}\mathrm{Kg} . \\
34.4 \\
50.3 \\
28.4 \\
73.6 \\
64.6 \\
80.2 \\
35.0 \\
73.8\end{array}$ & $\begin{array}{l}\text { Osteoarthritis } \\
\text { Rheumatoid arthritis } \\
\text { Rheumatoid spondylitis } \\
\text { Anal fissure } \\
\text { Inguinal hernia } \\
\text { Gout } \\
\text { Rheumatoid spondylitis } \\
\text { Rheumatoid arthritis }\end{array}$ & $\begin{array}{l}\text { None } \\
\text { None } \\
\text { None } \\
\text { None } \\
\text { None } \\
\text { ACTH } \\
\text { ACTH } \\
\text { Cortisone† }\end{array}$ & $\begin{array}{c}m g . \\
\text { X } \\
\text { X } \\
\text { X } \\
\mathrm{X} \\
\mathrm{X} \\
100 \\
100 \\
100\end{array}$ & $\begin{array}{r}\mathrm{X} \\
\mathrm{X} \\
\mathrm{X} \\
\mathrm{X} \\
\mathrm{X} \\
4 \\
39 \\
5\end{array}$ & $\begin{array}{l}\bar{z} \\
\bar{z} \\
21.8 \\
11.8\end{array}$ & $\begin{array}{l}10.6 \\
13.7 \\
10.8 \\
19.0 \\
13.2 \\
22.1 \\
12.4 \\
17.0\end{array}$ & $\begin{array}{l}10.6 \\
13.7 \\
10.9 \\
18.8 \\
13.8 \\
22.1 \\
12.5 \\
17.6\end{array}$ & $\begin{array}{l}10.7 \\
14.0 \\
10.1 \\
18.6 \\
13.9 \\
21.0 \\
12.0 \\
17.0\end{array}$ \\
\hline
\end{tabular}

* Bromide had been administered four weeks previously.

† Administered intramuscularly.

and one cortisone. Measurements were made at four, five, seven, and 24 hours both in untreated and ACTH treated patients. Correction for bromide excretion was applied to the 24 hour determination. It was observed that the spaces measured at four, five, seven, and 24 hours were in good agreement (Table I). In most of our data, the five hour, or average of the five and seven hour spaces is given. In patients in whom considerable weight gain as a result of ACTH administration had occurred, the five, seven and 24 hour spaces were measured to establish adequate equilibration.

When a number of estimations of the bromide space were made at approximately weekly intervals, the bromide blank value in some instances rose to levels approximating $50 \%$ of the total bromide concentration in the completely diffused in five hours, and that fall in the bromide ion concentration after five hours is due completely to excretion. Support for this assumption is presented in Table II.

Total body chloride: Weir and Hastings (10) and Wallace and Brodie (11) have shown that, except in brain and spinal fluid, bromide distributes itself in tissue in proportion to the chloride content, and that the ratio of the concentrations of bromide to chloride is constant in the different tissues of the body. This fact makes it possible to determine total body chloride, at least as an approximation, on the basis of the distribution of bromide. This has been done in man by Dunning, Steele, and Berger (8), and Deane, Ziff, and Smith (12). Total chloride was calculated according to the following formula :

$$
\text { Total mEq. } \mathrm{Cl}^{-}=\frac{\text { (mg. } \mathrm{Br}^{-} \text {administered }-\mathrm{mg} . \mathrm{Br}^{-} \text {excreted) } \times \mathrm{mEq} . \mathrm{Cl}^{-} / \mathrm{ml} \text {. plasma }}{\mathrm{mg} . \mathrm{Br}^{-} / \mathrm{ml} \text {. plasma }} .
$$

plasma (Table II). In order to correct for the change in the magnitude of high blank values as a result of excretion during determinations of the 24 hour space, the zero time blank value was corrected as follows :

$$
\underset{24 \mathrm{hr} .}{\text { Blank Value }}=\underset{\text { Blank Value }}{\mathrm{O} \mathrm{hr} .} \times \frac{\left[\mathrm{Br}^{-}\right] 24 \mathrm{hr} .}{\left[\mathrm{Br}^{-}\right] 5 \mathrm{hr} .}
$$

This correction assumes that administered bromide is
Serum electrolytes: Plasma potassium and serum sodium concentrations were determined on the flame photometer, serum chloride was determined by the method of Wilson and Ball (13) and plasma bicarbonate by the manometric method of Van Slyke and Neill (14). The serum chloride levels include bromide but the latter was less than $2 \%$ of the total halide.

Satisfactory eosinophil responses to ACTH (15) were

TABLE II

\begin{tabular}{|c|c|c|c|c|c|c|c|c|c|c|c|}
\hline \multirow[b]{2}{*}{ Patient } & \multirow[b]{2}{*}{ Age } & \multirow[b]{2}{*}{ Sex } & \multirow[b]{2}{*}{ Wt. } & \multirow[b]{2}{*}{$\begin{array}{l}\text { ACTH } \\
\text { dosage }\end{array}$} & \multirow[b]{2}{*}{ Days } & \multicolumn{4}{|c|}{ Bromide (mg. per $m l$. ) } & \multicolumn{2}{|c|}{ Bromide space (liters) } \\
\hline & & & & & & $\begin{array}{l}\text { Blank } \\
\text { value }\end{array}$ & $5 \mathrm{hr}$. & $24 \mathrm{hr}$. & $\begin{array}{c}\text { Blank } \\
\text { value } \\
(24 \mathrm{hr} .) \\
\text { corr. }\end{array}$ & $5 \mathrm{hr}$. & $24 \mathrm{hr}$. \\
\hline $\begin{array}{l}\text { H. C. } \\
\text { W. C. } \\
\text { W. C. } \\
\text { R. F. }\end{array}$ & $\begin{array}{c}y r s . \\
17 \\
42 \\
42 \\
14\end{array}$ & $\begin{array}{l}\mathbf{F} \\
\mathbf{F} \\
\mathbf{F} \\
\mathbf{M}\end{array}$ & $\begin{array}{c}K g . \\
50.7 \\
51.8 \\
58.0 \\
61.2\end{array}$ & $\begin{array}{c}\text { mg. per day } \\
100 \\
120 \\
120 \\
100\end{array}$ & $\begin{array}{r}12 \\
4 \\
18 \\
47\end{array}$ & $\begin{array}{l}.087 \\
.089 \\
.159 \\
.105\end{array}$ & $\begin{array}{l}.164 \\
.194 \\
.224 \\
.191\end{array}$ & $\begin{array}{l}.157 \\
.186 \\
.209 \\
.174\end{array}$ & $\begin{array}{l}.083 \\
.085 \\
.148 \\
.096\end{array}$ & $\begin{array}{l}15.9 \\
15.1 \\
22.1 \\
17.9\end{array}$ & $\begin{array}{l}16.2 \\
15.1 \\
21.9 \\
17.7\end{array}$ \\
\hline
\end{tabular}

Bromide spaces measured at five and 24 hour intervals in ACTH treated patients who had previously received bromide 
TABLE III

Repetition of space and body chloride determinations in same individual untreated with $A C T H$

F. R., Male, 53 (Rheumatoid arthritis)

\begin{tabular}{l|r|r|r|r}
\hline \hline \multirow{2}{*}{ Determination } & \multicolumn{4}{|c}{ Day } \\
\cline { 2 - 5 } & 1 & 5 & 10 & 16 \\
\hline Plasma volume (liters) & 2.78 & - & 2.98 & 2.91 \\
Bromide space* (liters) & 15.5 & 16.0 & 14.8 & 15.3 \\
Total body Cl (mEq.) & 1,810 & 1,850 & 1,720 & 1,770 \\
Antipyrine space (liters) & 36.5 & 35.3 & 35.6 & 36.8 \\
Weight (Kg.) & 59.5 & 58.6 & 59.8 & 60.7 \\
\hline
\end{tabular}

* Five hour space.

noted in all patients treated with this hormone except E. S. 5

\section{RESULTS}

It may be seen from Table I that in untreated as well as in ACTH treated patients who had not received bromide previously, bromide spaces at four, five, seven and 24 hours were essentially equivalent. In Table II are presented measurements of the bromide space in ACTH treated patients who had received bromide in previous experiments and in whom the zero hour blank was corrected for excretion during the 24 hour period as described. The five and 24 hour spaces are in good agreement.

In order to determine the precision of the determinations used, $\mathrm{T} 1824$, antipyrine and bromide spaces were measured four times within a one week period in the same individual, a 46-year-old man with moderately advanced rheumatoid arthritis (Table III). The widest variation in four determinations was 0.2 liter in the $\mathrm{T} 1824$ space, 1.2 liters in the bromide space, 1.5 liters in the antipyrine space, and $130 \mathrm{mEq}$. in the calculated body chloride.

In Figures 1 to 5 are plotted the changes in bromide space, total body chloride, antipyrine

\footnotetext{
5 In this patient, the eosinophil count, initially 321 , fell to 108 after 14 days and to 21 after 17 days of ACTH administration, remaining reduced during the remainder of the period of hormonal therapy. The pre-treatment 17ketosteroid excretion was $6.8 \mathrm{mg}$. and rose to $21 \mathrm{mg}$. after 17 days of treatment. Serum electrolyte concentrations, Robinson-Power-Kepler excretion test and glucose tolerance tests were within normal limits. There were no clinical evidences of adrenal,insufficiency. The response to treatment was somewhat delayed but adequate after the first week of therapy.
}

space and weight occurring in individual patients during and after ACTH administration. These are represented as increments above the control values obtained prior to $\mathrm{ACTH}$ administration. They have been plotted on a common scale of ordinates so that 1 liter of antipyrine or bromide space, $1 \mathrm{Kg}$. of weight and $100 \mathrm{mEq}$. of chloride each have the same dimension. T 1824 volumes are also given.

\section{Effects of $A C T H$ administration to patients}

(Figures 1-5)

\section{1). F. R., Rheumatoid arthritis, male, age 53}

When studied at six and 18 days after the start of ACTH administration, the patient demonstrated (Figure 1) marked expansion of the anitipyrine space, bromide space and total body chloride. After 18 days, 8.1 liters of water had been gained, a $22 \%$ increase over the original volume. The bromide space increased 8.9 liters, and the weight $8.9 \mathrm{Kg}$. It would appear that the increases in body weight and body water were accounted for by the expansion of the bromide space. T 1824 space increased from 2.9 to 4.1 liters during this period, and the hematocrit fell from 38 to 30 . The patient, who was free of cardiac disease, demonstrated mild exertional dyspnea and pitting edema of the legs and presacral region at this time. The venous pressure was $200 \mathrm{~mm}$. of water and the right auricular pressure rose to $9 \mathrm{~mm}$. of $\mathrm{Hg}^{6}$

Ten days after ACTH therapy was discontinued, marked decreases of approximately equal magnitude had occurred in all compartments measured. The venous pressure had returned to normal, and there was no edema. Serum electrolyte levels $\left(\mathrm{Na}^{+}, \mathrm{K}^{+}, \mathrm{Cl}^{-}\right.$, and $\left.\mathrm{HCO}_{3}{ }^{-}\right)$remained within normal limits during and after ACTH administration (Table IV).

\section{2). G.R., Rheumatoid spondylitis, with peripheral joint involvement, male, age 52}

This patient was free of cardiac disease but had $2+$ pitting edema of the feet associated with joint involvement of both ankles. As in the preceding patient, after ACTH had been administered for 13 days (Figure 2 ), there was a $26 \%$ increase in

${ }^{6}$ Cardiac catheterizations referred to in this paper were done by Drs. Ludwig W. Eichna, Roy Albert, and Warren Smith. 


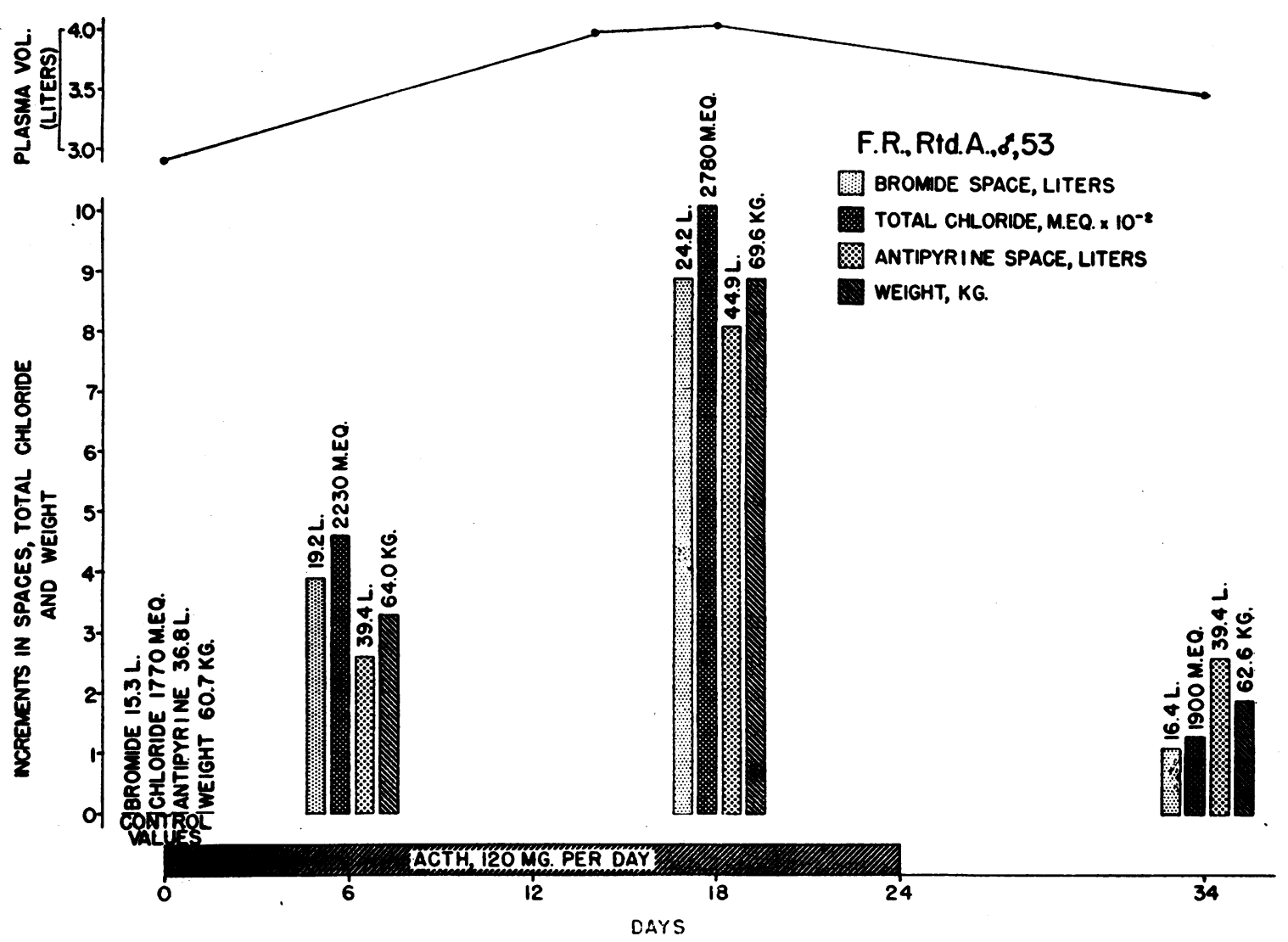

Fig. 1. Patient F. R. Increments in Spaces, Total Chloride, and Weight above Control Values Obtained Prior to ACTH Administration

total body water, amounting to 8.1 liters, and there were increases of approximately equal magnitude in bromide space and body weight. Here again the weight and water gain were equalled by the expansion of the bromide space. The T 1824 space varied in an opposite direction to the bromide and antipyrine spaces, decreasing from 4.1 to 3.4 liters during the 13 day period. This change was accompanied by a rise in the hematocrit from 28 to 32 . Serum $\mathrm{K}^{+}$concentration fell from 5.5 to 3.0 $\mathrm{mEq}$. per liter and serum $\mathrm{Cl}^{-}$from 106 to $96 \mathrm{mEq}$. Sodium levels remained within normal limits.

3). M. U., Rheumatoid arthritis, female, age 28

During the first eight days of treatment (Figure 3 ), the patient responded like the preceding ones with significant and approximately equal expansions of the antipyrine space, bromide space, total body chlorides, and body weight. After 19 days of treatment, however, the water and weight increments were significantly greater than the ex- pansion of the bromide space, and after 33 days this divergence was even more marked. Whereas the bromide space had increased only 2.2 liters above the pre-ACTH level, body water had increased 5 liters and the weight $6.5 \mathrm{Kg}$. Six days. following discontinuance of $\mathrm{ACTH}$, the bromide and antipyrine spaces had diminished in volume approximately 1 liter to 1.5 liters. Eight days after ACTH was stopped, her weight had diminished only $1.4 \mathrm{Kg}$. or $22 \%$ of the maximum increment. T 1824 space showed a gradual increase during therapy, going from 2.1 to 2.6 liters in 25 days, and returning to the original value after discontinuance of ACTH. Serum electrolytes remained at normal values throughout. The patient developed no edema nor manifestations of cardiac decompensation.

\section{4). L. G., Rheumatic fever, male, age 40}

This patient had a history of rheumatic polyarthritis with fever and a $20 \mathrm{lb}$. weight loss during a 

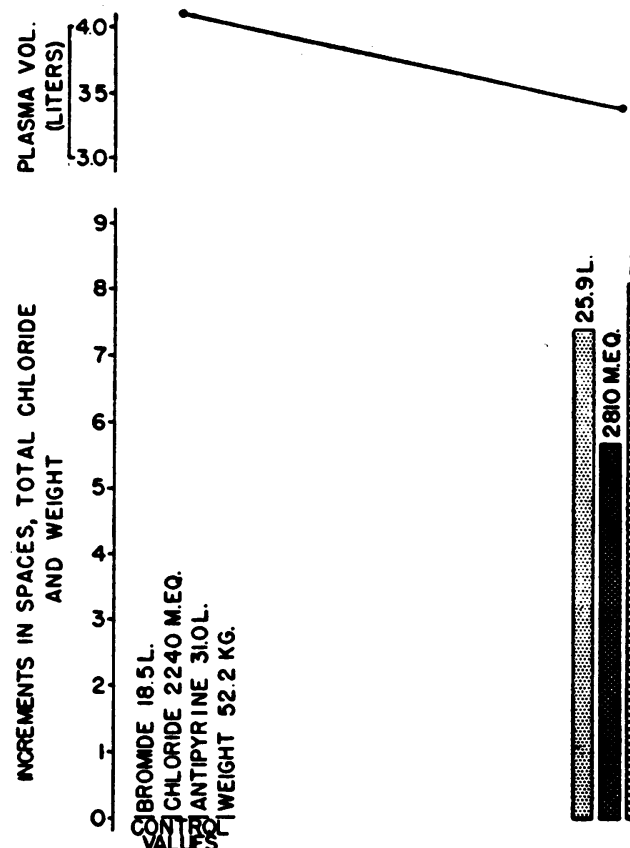

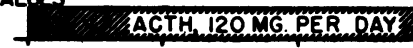

4 ATH

DAYS
G.R. Morie-Strumpell,\&,52

BROMIDE SPACE, LITERS

TOTAL CHLORIDE, M.EO $\times 10^{\circ}$

ANTIPYRINE SPACE, LITERS

WEIGHT, KG.

Fig. 2. Patient G. R. Increments in Spaces, Total Chloride, and Weight above Control Values.
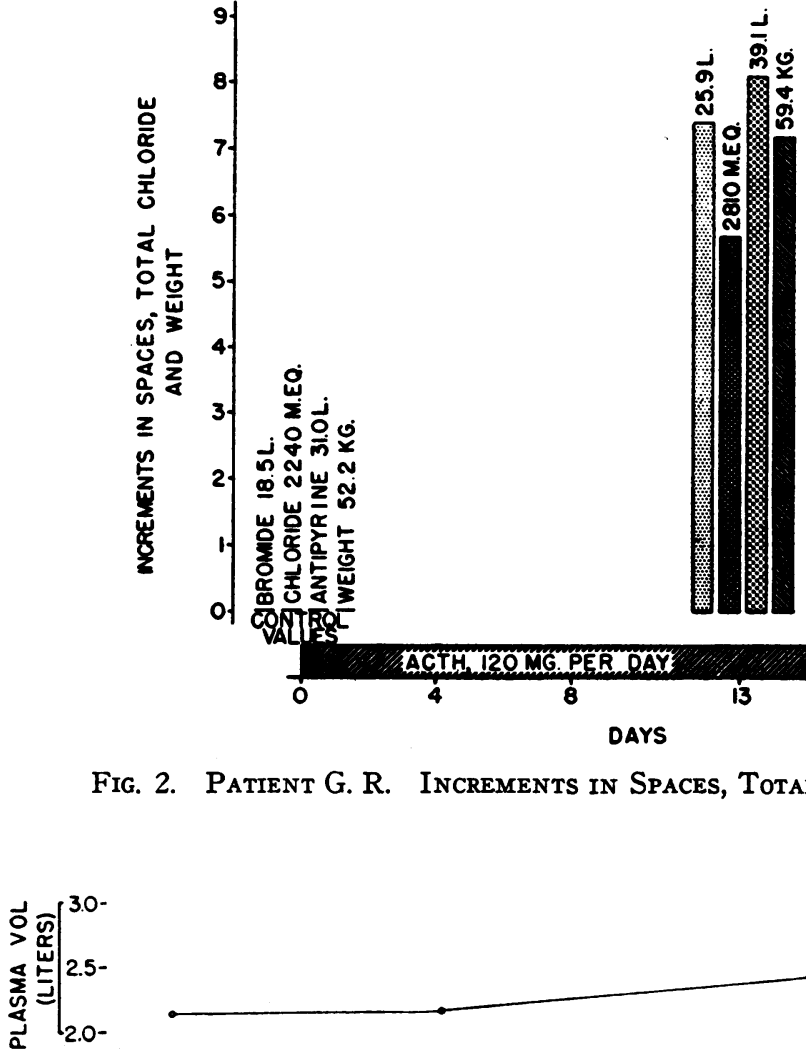

8-

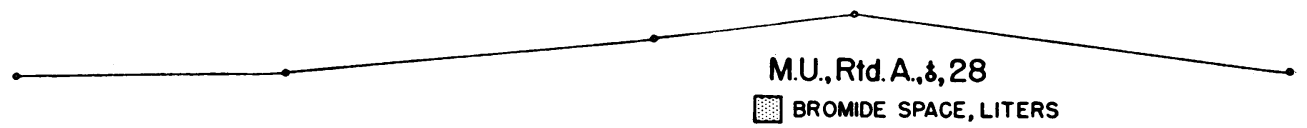

MROMIDE SPACE, LITERS

TOTAL CHLORIDE, M.EQ. $\times 10^{-2}$

ANTTPYRINE SPACE, LITERS

WEIGHT, KG.

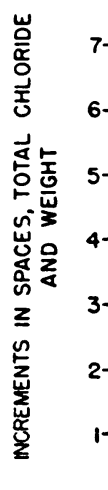

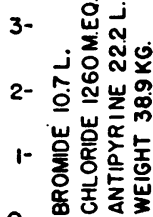

0 CALTRE
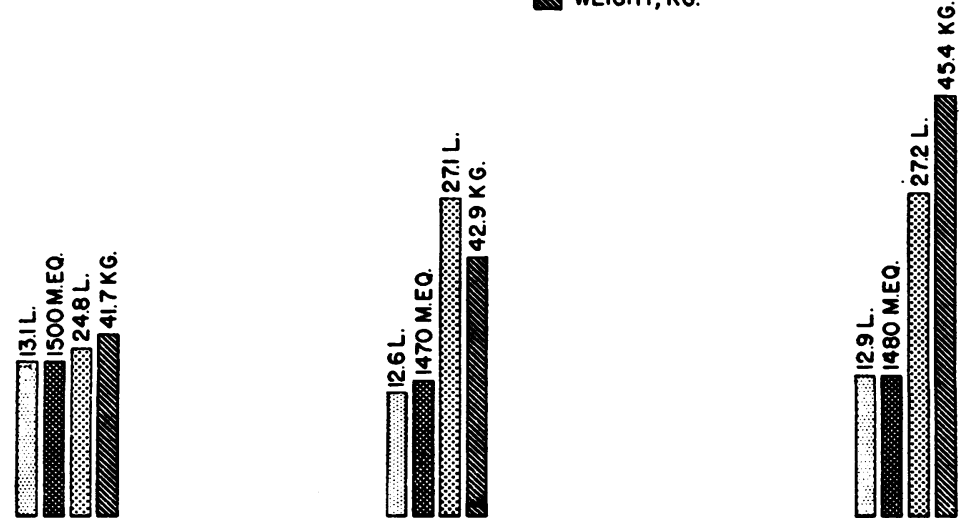

$80 \mathrm{MG}$

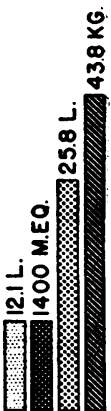
TITI A ' TH

19
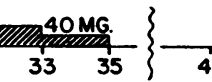

DAYS

Fig. 3. Patient M. U. Increments in Spaces, Total Chloride, and Weight above Control Values 
TABLE IV

Serum electrolyte concentrations and hematocrits before, during and after administration of $A C T H$

\begin{tabular}{|c|c|c|c|c|c|c|}
\hline Patient & Day & $\mathrm{Na}^{+}$ & $\mathrm{K}^{+}$ & $\mathrm{Cl}^{-}$ & $\mathrm{HCO}_{3}^{-}$ & Het. \\
\hline F. R. & $\begin{array}{c}\text { Control } \\
6 \\
18 \\
34\end{array}$ & $\begin{array}{c}m E q . / L \\
139 \\
143 \\
138 \\
135\end{array}$ & $\begin{array}{c}m E q . / L \\
3.9 \\
3.3 \\
4.2 \\
4.6\end{array}$ & $\begin{array}{c}m E q . / L \\
102 \\
102 \\
100 \\
104\end{array}$ & \begin{tabular}{|c}
$m E q . / L$. \\
24.1 \\
25.2 \\
26.2 \\
22.5
\end{tabular} & $\begin{array}{l}38 \\
36 \\
30 \\
32\end{array}$ \\
\hline G. R. & $\begin{array}{c}\text { Control } \\
13\end{array}$ & $\begin{array}{l}141 \\
134\end{array}$ & $\begin{array}{l}5.5 \\
3.0\end{array}$ & $\begin{array}{r}106 \\
96\end{array}$ & - & $\begin{array}{l}28 \\
36\end{array}$ \\
\hline M. U. & $\begin{array}{c}\text { Control } \\
8 \\
19 \\
25 \\
33 \\
41\end{array}$ & $\begin{array}{l}140 \\
141 \\
139 \\
134 \\
141 \\
136\end{array}$ & $\begin{array}{l}4.6 \\
4.1 \\
3.4 \\
4.3 \\
3.5 \\
3.8 \\
3.8\end{array}$ & $\begin{array}{r}104 \\
102 \\
103 \\
100 \\
99 \\
102\end{array}$ & $\begin{array}{l}22.5 \\
22.5 \\
29.7 \\
26.2 \\
24.7 \\
24.4\end{array}$ & $\begin{array}{l}31 \\
32 \\
33 \\
34 \\
34 \\
34\end{array}$ \\
\hline L. G. & $\begin{array}{c}\text { Control } \\
11 \\
19 \\
21 \\
33 \\
41\end{array}$ & $\begin{array}{l}140 \\
137 \\
134 \\
138 \\
137 \\
137\end{array}$ & $\begin{array}{l}4.8 \\
4.5 \\
3.5 \\
3.5 \\
3.9 \\
3.9\end{array}$ & $\begin{array}{l}102 \\
101 \\
101 \\
103 \\
105 \\
104\end{array}$ & $\begin{array}{l}19.8 \\
26.1 \\
26.1 \\
26.8 \\
23.6 \\
23.4\end{array}$ & $\begin{array}{l}37 \\
38 \\
37 \\
37 \\
37 \\
37\end{array}$ \\
\hline E. S. & $\begin{array}{c}\text { Control } \\
6 \\
10 \\
25 \\
35\end{array}$ & $\begin{array}{l}135 \\
140 \\
141 \\
134 \\
136\end{array}$ & $\begin{array}{l}5.1 \\
3.4 \\
3.3 \\
3.7 \\
3.1\end{array}$ & $\begin{array}{r}98 \\
100 \\
95 \\
94 \\
97\end{array}$ & $\begin{array}{l}-\overline{26.1} \\
25.2 \\
24.7 \\
28.3\end{array}$ & $\begin{array}{l}31 \\
33 \\
35 \\
37 \\
36\end{array}$ \\
\hline
\end{tabular}

period of one month prior to treatment with ACTH. There was no evidence of rheumatic carditis. The disease was active and the patient febrile when therapy was instituted. After 11 days of ACTH administration, he had gained $7.5 \mathrm{Kg}$. and 8.2 liters of water (Figure 4). This was accompanied by only a negligible increase in bromide space and total body chloride. The latter two quantities increased somewhat as treatment was continued, but after 21 days the bromide space was only 1.5 liters above the pre-ACTH value, whereas the antipyrine space had increased 6.4 liters. The weight had increased $8.4 \mathrm{Kg}$. at this time. Sixteen days after ACTH had been discontinued, the total body water still remained at its expanded volume and the patient had gained an additional $2.2 \mathrm{Kg}$. of weight. Bromide space had shown a comparatively small decrease. T 1824 volume rose from 3.5 to 4.2 liters during the 21 days of ACTH administration and did not fall after this was discontinued. Hematocrit was unchanged and serum electrolyte concentrations remained within normal limits throughout. Cardiac
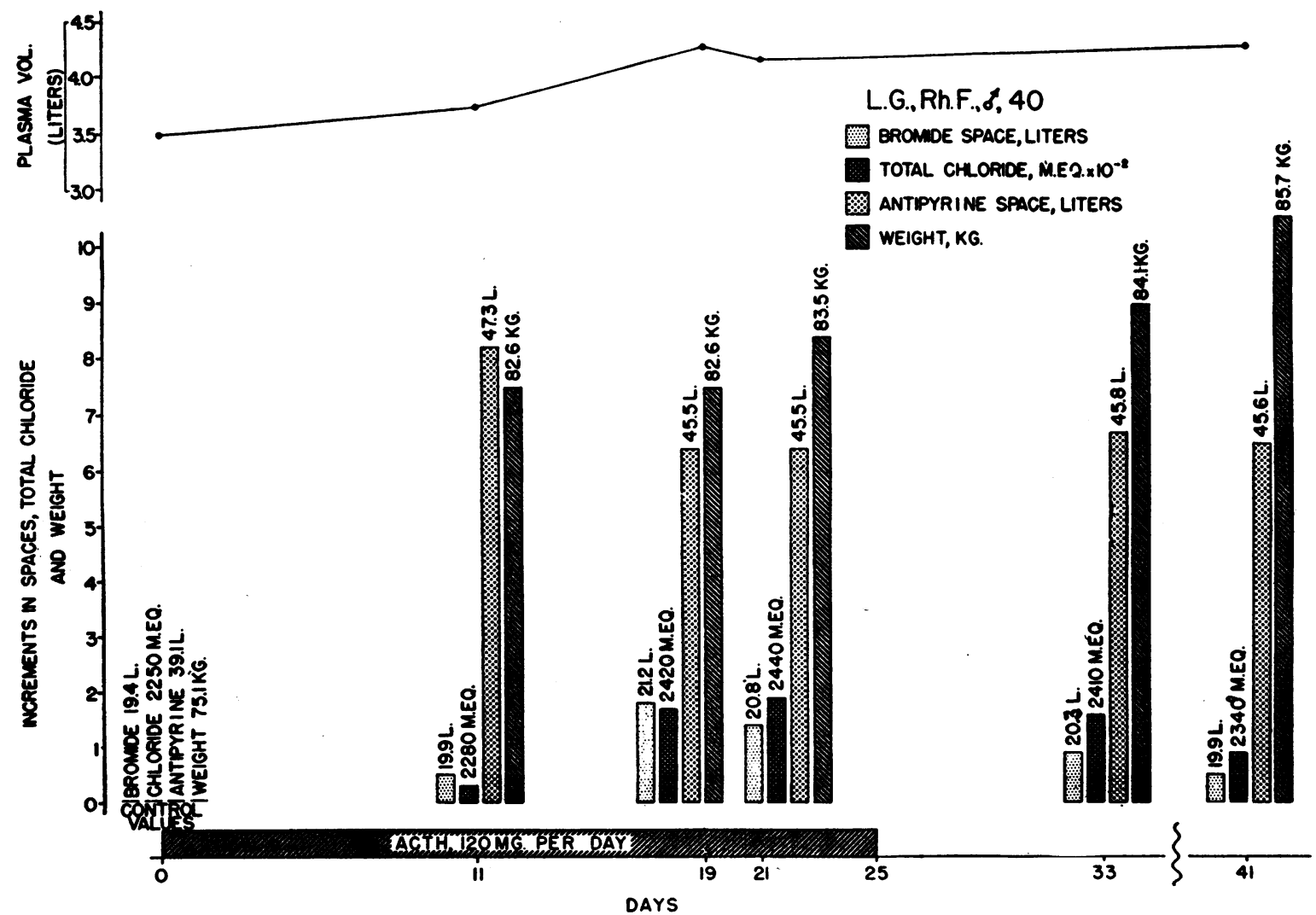

Fig. 4. Patient L. G. Increments in Spaces, Total Chloride, and Weight above Control Values 

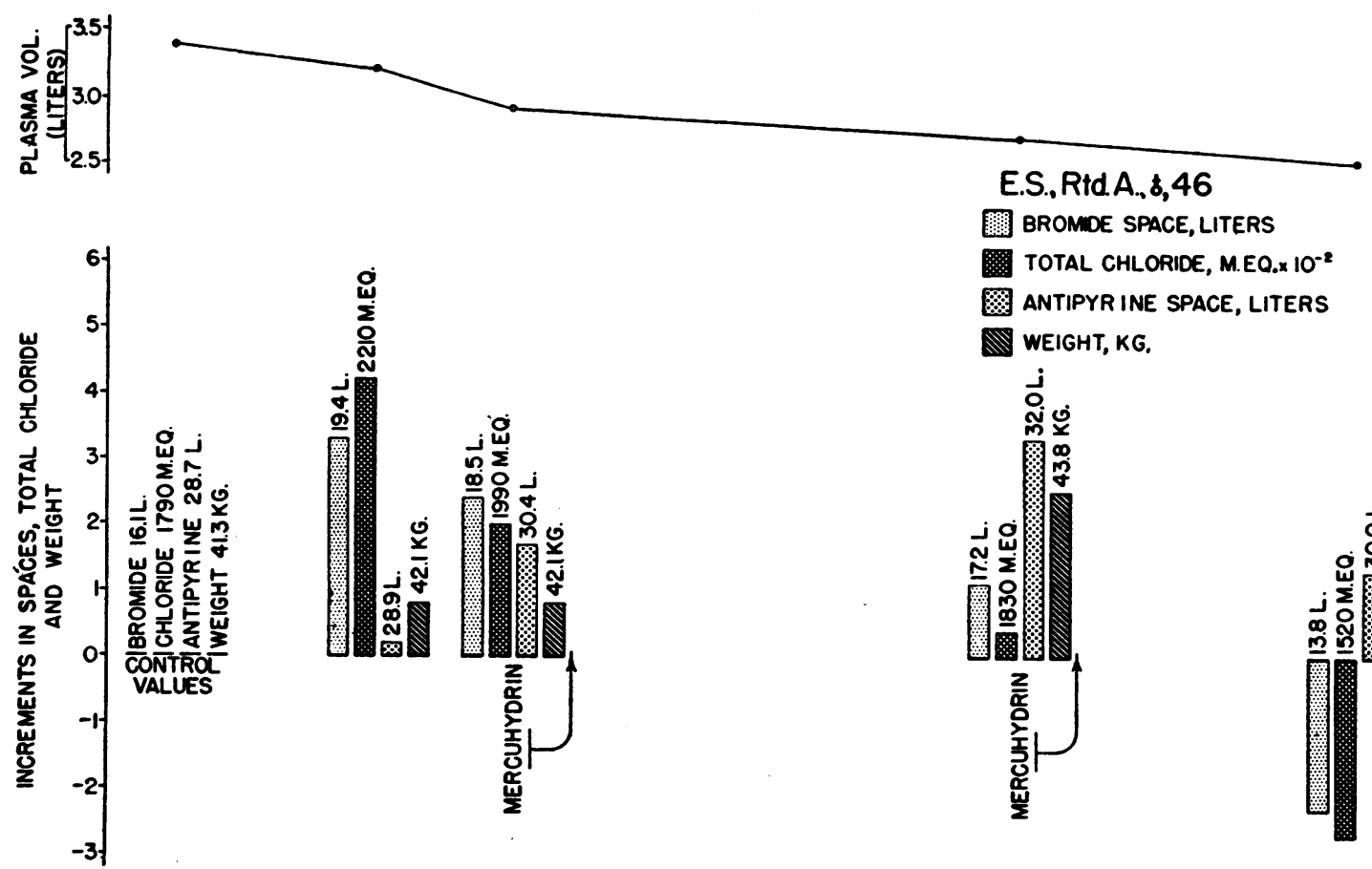

E.S. Rtd. A. 8,46

Tivin BROMDE SPACE, LITERS

TOTAL CHLORIDE, M.EO.x $10^{-2}$

ANTIPYRINE SPACE, LITERS

WEIGHT, KG.
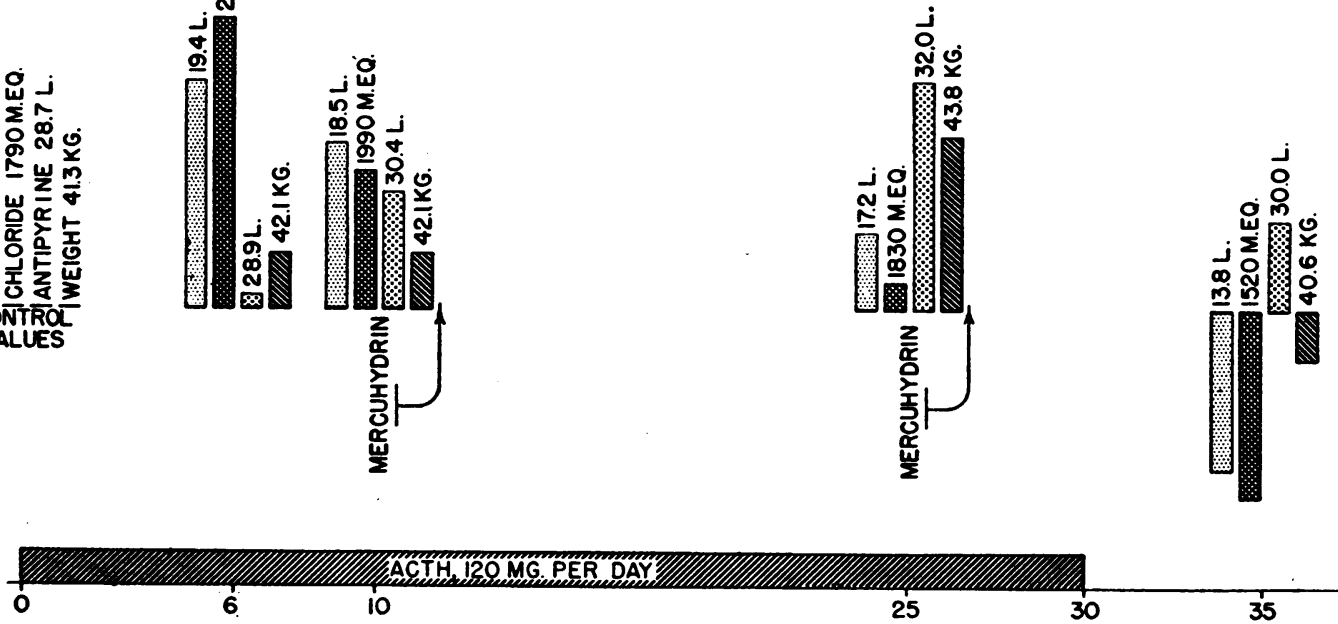

DAYS

25

35

Fig. 5. Patient E. S. Increments in Spaces, Total Chloride, and Weight above Control Values

Mercuhydrin $(2 \mathrm{ml}$.) was injected intramuscularly following the space determinations on the 10 th and 25 th days of ACTH administration.

catheterization was done on the 19th day of therapy and the results indicated no abnormality of cardiac function. The patient had no symptoms or signs of diminished cardiac reserve.

\section{5). E. S., Rheumatoid arthritis, female, age 46}

This patient had advanced rheumatoid arthritis and evidence of inactive chronic heart disease, consisting of cardiac enlargement and insufficiency of the mitral valve. There were no signs of failure. Six days after the administration of ACTH, she had retained $420 \mathrm{mEq}$. of chloride (Figure 5). This was accompanied by an increase of 3.3 liters of the bromide space, but only by a negligible increase in body water and body weight. There was at this time dyspnea at rest, mild pitting edema of the ankles, and a venous pressure of $160 \mathrm{~mm}$. of water. Following space studies, a mercurial diuretic was injected to relieve the symptoms of failure. As ACTH was continued, there was a diminution in the bromide space and body chloride. This was accompanied, however, by a rise in total body water and weight. At 25 days, the bromide space and total chloride had returned almost to control levels whereas total body water had increased 3.3 liters above the pre-ACTH value. At this time the patient was again complaining of dyspnea and orthopnea, the liver was enlarged, there was edema of the lower extremities and the venous pressure was $160 \mathrm{~mm}$. of water. Blood circulation times were within normal limits. Following space studies, a mercurial diuretic was again given. Five days after ACTH was discontinued, there was a marked diminution of bromide space and total chloride to significantly less than pre-ACTH levels. This was accompanied by smaller, though significant, losses in body weight and water.

T 1824 space showed a steady fall throughout therapy, diminishing from a pre-treatment value of 3.4 liters to a volume of 2.7 liters after 25 days of ACTH, and remaining at approximately this level, five days after the hormone was discontinued. The hematocrit rose from 31 to 37 and the hemoglobin from 10 to 11.5 grams in the course of the 25 day period of ACTH administration. Serum $\mathrm{Na}^{+}$ 
remained within normal limits throughout the period of observation; $\mathrm{K}^{+}$concentration fell from 5.1 $\mathrm{mEq}$. to $3.7 \mathrm{mEq}$. per liter at 25 days; serum chloride varied from 98 to $94 \mathrm{mEq}$; and the $\mathrm{HCO}_{3}{ }^{-}$ level rose to $29.7 \mathrm{mEq}$. at this time.

\section{COMMENT}

It has been demonstrated $(10,11)$ that bromide is distributed similarly to chloride in body tissues. The volume of distribution of bromide, like that of chloride, thiocyanate, and sodium, is larger than that of inulin and sucrose $(7,12,16)$, and it has been suggested, for this reason, that approximately $30 \%$ of body chloride (12) is intracellular. If it is accepted that chloride exists intracellularly in significant amounts, expansion of the bromide space induced by ACTH may reflect in part change in intracellular as well as extracellular fluid volume. Antipyrine space (4a) was utilized to measure total body water. Evidence that the volume of distribution of antipyrine is equivalent to total water is the observed agreement between antipyrine space and deuterium oxide (4a) and tritium oxide spaces (4b).

In two patients, F. R. and G. R., there were large increases in total body water, which paralleled quite closely weight gain and expansion of the bromide space. In these patients, it would appear that the increase in body water was associated largely with expansion of the chloride compartment. This is consistent with the fact that both patients developed increasing edema and that in one (F. R.) the venous pressure rose to abnormal levels. In M. U. and L. G., however, the expansion of the chloride compartment did not keep pace with the increase in total body water. This could in part be due to the tendency to loss of chloride with alkalosis which is known to occur in patients with hyperadrenalcorticalism (1), but significant abnormality of serum electrolyte concentrations was not noted in either individual. It is likely that the water increments in M. U. and L. G. represent largely expansion of the intracellular compartment, which is ordinarily associated predominantly with retention of anions other than chloride. This could in great part be due to repair of atrophic muscle tissue, $83 \%$ of which, according to Hastings and Eichelberger (17), consists of intracellular phase of which $72 \%$ is water.
The history of marked weight loss prior to therapy and the absence of a water diuresis exhibited by L. G., and similarly the small diuresis observed in M. U. following discontinuance of $\mathrm{ACTH}$, are consistent with this explanation. The relatively greater increase in body weight than body water observed in these two cases at the termination of therapy may be explained by the deposition of significant amounts of body fat and tissue solids.

E. S., who had advanced rheumatoid arthritis and also heart disease, showed a pattern of response to ACTH which differed from the other four. There was early increase in body chloride and bromide space, without concurrent expansion of body water or body weight. Simultaneously there appeared symptoms and signs of congestive heart failure. A somewhat similar phenomenon has been reported by Levitt and Bader (2), and has been attributed by these authors to a shift of salt and water extracellularly. In the case of chloride, this would have to arise from stores which previously did not exchange with bromide. With continuation of ACTH therapy and the administration of two mercurial injections, there was a loss of body chloride and, five days after discontinuing ACTH, total body chloride and bromide space were well below pretreatment values.

The plasma volume rose with ACTH administration in three patients and fell in two. In four out of five, changes in plasma volume corresponded fairly well with changes in the bromide space. In G. R., plasma volume fell as bromide space rose. Jager, Brown and Nickerson (18a) noted an increase in plasma volume in three patients out of five receiving $\mathrm{ACTH}$; in the other two patients there was a large and small decrease, respectively. ${ }^{7}$ The authors suggest that shifts of protein into and out of the vascular compartment, induced by ACTH, might play a role in altering the plasma volume. Repair of anemia may be a potent factor in decreasing plasma volume. Thus, in G. R. there was a rise in hemoglobin from 9 to 11 grams during ACTH therapy, and the hematocrit rose

\footnotetext{
7 Copeman and co-workers (18b) have recently observed a fall of plasma volume in all of three patients studied, who were being treated with cortisone; this occurred in spite of the fact that all showed some degree of fluid retention.
} 
from 28 to 32 . The possibility of alteration in capillary permeability to $\mathrm{T} 1824$ as a result of adrenal cortical stimulation should also be considered as a factor affecting the measured blood volume. Change in capillary permeability to $\mathrm{T}$ 1824 , in rats treated with cortisone (19), was not observed, however, when hyaluronidase was not injected simultaneously.

The suggestion has been made by McMaster and Parsons (20) on the basis of microscopic observations of the manner of interstitial movement of vitally injected dyes that there is no free fluid, in the ordinary sense, in the ground substance of normal connective tissue. These authors could not identify the presence of freely movable fluid in the interstitial space. The demonstration of permeability changes in tissue treated locally with hyaluronidase and cortisone $(21,22)$ raises the question as to whether the extent of diffusion of materials through the ground substance, with which the water may be bound, might be altered sufficiently by hormonal therapy to affect the measured total body water. Increase in antipyrine space without at least an equivalent gain in weight was not observed, however, in the present studies. Nevertheless, the possibility of diminution in antipyrine space because of decreased permeability, such as occurs with prolonged local treatment with cortisone (23), cannot be ruled out.

Assays of the lot of ACTH used, ${ }^{8}$ done in the laboratory of Dr. E. P. Ralli, indicated the presence of 20 milliunits of antidiuretic (ADH) activity (24) per mg. of ACTH (Armour Standard LA-1-A). Thus each dose of $25 \mathrm{mg}$. contained 500 milliunits of $\mathrm{ADH}$ activity. It would appear unlikely that this dosage in aqueous solution, given at six hour intervals, would by itself bring about a sustained retention of water. Lloyd, Harris, and Lobotsky (25) observed no gain in weight in two normal individuals receiving daily injections of pitressin tannate in oil. Robinson and Farr (26) administered 30 units of pitressin per day to humans and, though there was an early rise in urinary $\mathrm{ADH}$, it fell rapidly to normal in a few days. The combined effect of ACTH and pitressin on water and salt balance is a subject about which there is as yet little information (27).

\footnotetext{
8 J-16709 R, Armour and Co.
}

It would appear from the present work, that the amount of water retention, and the manner in which this is retained in response to ACTH varies in different individuals, being in some predominantly extracellular and in others intracellular. Variability of response to adrenal cortical hormones under differing physiological conditions has been noted commonly. Cortisone may, under different circumstances, cause either water retention or water diuresis (27). Impairment of glucose tolerance may occur in some patients after a brief period of cortisone administration, and in others no impairment is demonstrable even after prolonged administration (28). Nitrogen balance may be either positive or negative according to existing tissue requirements (29). It may be that the manner in which water is retained in response to ACTH is determined among other things by the tissue needs of the subject. Thus, water retention appeared to be intracellular in L. G., for example, in whom body solids increased, and extracellular in F. R. in whom body solids did not increase.

\section{SUM MARY}

Simultaneous determinations of $\mathrm{T} 1824$, antipyrine and bromide spaces were made before, during and after ACTH therapy in five patients with rheumatic diseases. Total body chloride was calculated at the same time. The following observations were made:

1) On administration of ACTH, marked increases in body water were consistently observed in all cases. 2) In two patients who developed increasing edema on administration of ACTH, one of whom demonstrated elevation of venous pressure, the expansion of antipyrine space and gain in body weight were similar in magnitude to increase in the bromide space, indicating retention of water predominantly in the extracellular compartment. 3) In two patients in whom edema or signs of venous congestion were not evident, increase in antipyrine space and body weight exceeded the increment in bromide space. The water increments in these patients appeared to be due mainly to retention of intracellular water associated with gain in tissue weight. 4) In one patient there was an initial increase in bromide space with retention of chloride, which later diminished in 
spite of an increase in total body water. 5) T 1824 space rose in three patients and fell in two during administration of ACTH. It varied directly with the bromide space in four patients out of five. 6) The manner of water retention by different individuals in response to $\mathrm{ACTH}$ is variable.

\section{ACKNOWLEDGMENTS}

We are grateful to Dr. Denys Ford for his cooperation in this investigation, and to Mrs. Jennie Shatton, $\mathrm{Mr}$. Harold Kadin, and Mr. Martin Tanner for their technical assistance.

\section{REFERENCES}

1. Sprague, R. G., Power, M. H., Mason, H. L., Albert, A., Mathieson, D. R., Hench, P. S., Kendall E. C., Slocumb, C. H., and Polley, H. F., Observations on the physiologic effects of cortisone and ACTH in man. Arch. Int. Med., 1950, 85, 199.

2. Levitt, M. F., and Bader, M. E., Effect of cortisone and ACTH on fluid and electrolyte distribution in man. Am. J. Med., 1951, 11, 715.

3. Gregersen, M. I., A practical method for the determination of blood volume with the dye T-1824. A survey of the present basis of the dye-method and its clinical application. J. Lab. \& Clin. Med., 1944, 29, 1266.

4a. Soberman, R., Brodie, B. B., Levy, B. B., Axelrod, J., Hollander, V., and Steele, J. M., The use of antipyrine in the measurement of total body water in man. J. Biol. Chem., 1949, 179, 31.

4b. Prentice, T. C., Siri, W., Berlin, N. I., and Parsons, R. J., Clinical and experimental studies with tritium. J. Clin. Invest., 1952, 31, 654.

5. Brodie, B. B., and Friedman, M. M., The determination of bromide in tissues and biological fluids. J. Biol. Chem., 1938, 124, 511.

6. Brodie, B. B., Brand, E., and Leshin, S., The use of bromide as a measure of extracellular fluid. $\mathrm{J}$. Biol. Chem., 1939, 130, 555.

7. Berger, E. Y., Dunning, M. F., Steele, J. M., Jackenthal, R., and Brodie, B. B., Estimation of intracellular water in man. Am. J. Physiol., 1950, 162, 318.

8. Dunning, M. F., Steele, J. M., and Berger, E. Y., Measurement of total body chloride. Proc. Soc. Exper. Biol. \& Med., 1951, 77, 854.

9. Eliel, L. P., Pearson, O. H., and Rawson, R. W., Post-operative potassium deficit and metabolic alkalosis. New England J. Med., 1950, 243, 471; $1950 ; 243,518$.

10. Weir, E. G., and Hastings, A. B., The distribution of bromide and chloride in tissues and body fluids. J. Biol. Chem., 1939, 129, 547.
11. Wallace, G. B., and Brodie, B. B., Distribution of administered bromide in comparison with chloride and its relation to body fluids. J. Pharmacol. \& Exper. Therap., 1939, 65, 214.

12. Deane, N., Ziff, M., and Smith, H. W., The distribution of total body chloride in man. J. Clin. Invest., 1952, 31, 200.

13. Wilson, D. W., and Ball, E. G., A study of the estimation of chloride in blood and serum. J. Biol. Chem., 1928, 79, 221.

14. Van Slyke, D. D., and Neill, J. M., The determination of gases in blood and other solutions by vacuum extraction and manometric measurement. I. J. Biol. Chem., 1924, 61, 523.

15. Forsham, P. H., Thorn, G. W., Prunty, F. T. G., and Hills, A. G., Clinical studies with pituitary adrenocorticotropin. J. Clin. Endocrinol., 1948, 8, 15.

16. Levitt, M. F., and Gaudino, M., Measurement of body water compartments. Am. J. Med., 1950, 9, 208.

17. Hastings, A. B., and Eichelberger, L., The exchange of salt and water between muscle and blood. I. The effect of an increase in total water produced by the intravenous injection of isotonic salt solutions. J. Biol. Chem., 1937, 117, 73.

18a. Jager, B. V., Brown, H., and Nickerson, M., Alterations in plasma proteins, plasma volume, and volume of packed red cells in patients receiving ACTH or cortisone. J. Lab. \& Clin. Med., 1951, 73, 431.

18b. Copeman, W. S. C., Savage, O., Bishop, P. M. F., Dodds, E. C., Kellie, A. E., Steward, J. W., Glyn, J. H. H., Henly, A. A., and Tweed, J. M., Observations on prolonged cortisone administration in rheumatoid arthritis. Brit. M. J., 1952, 1, 397.

19. Benditt, E. P., Schiller, S., Wong, H., and Dorfman, A., Influence of ACTH and cortisone upon alteration in capillary permeability induced by hyaluronidase in rats. Proc. Soc. Exper. Biol. \& Med., 1950, 75, 782.

20. McMaster, P. D., and Parsons, R. J., Physiological conditions existing in connective tissue. II. The state of the fluid in the intradermal tissue. J. Exper. Med., 1939, 69, 265.

21. Opsahl, J. C., The influence of hormones from the adrenal cortex on the dermal spread of India ink with and without hyaluronidase: preliminary report. Yale J. Biol. \& Med., 1948-49, 21, 255. The role of certain steroids in the adrenal hyaluronidase relationship. Ibid., 1949, 22, 115.

22. Winter, C. A., and Flataker, L., Influence of cortisone and related steroids on the spreading effect of hyaluronidase. Federation Proc., 1950, 9, 137.

23. Hayes, M. A., and Bridgeman, R. M., Dermal spreading of hyaluronidase as influenced by prolonged local treatment with certain steroid hormones. Proc. Soc. Exper. Biol. \& Med., 1951, 77, 597.

24. Burns, J. H., Estimation of the antidiuretic potency of pituitary (posterior lobe) extract. Quart. J. Pharm. \& Pharmacol., 1931, 4, 517. 
25. Lloyd, C. W., Harris, J. F., and Lobotsky, J., Some studies of posterior pituitary and adrenal cortical interrelationships. J. Clin. Invest., 1951, 30, 657.

26. Robinson, F. H., Jr., and Farr, L. E., The relation between clinical edema and the excretion of an antidiuretic substance in the urine. Ann. Int. Med., 1940, 14, 42.

27. Gaunt, R., The adrenal cortex in salt and water metabolism. Recent Progress in Hormone Research, 1951, 6, 247.
28. Sprague, R. G., Mason, H. L., and Power, M. H., Physiologic effects of cortisone and ACTH in man. Recent Progress in Hormone Research, 1951, 6, 315 .

29. Browne, J. S. L., Discussion in Browne, J. S. L., Johnson, L. G., Schenker, V., and Venning, E. H., Protein metabolism in acute and chronic disease and the relation of protein metabolism to the excretion of glucocorticoids, in: Proceedings of the First Clinical ACTH Conference, edited by Mote, J. R. Blakiston Co., Philadelphia, 1950, p. 127. 